\title{
Use of UFLC-PDA for the analysis of organic acids in thirty five species of food and medicinal plants
}

\author{
Carla Pereira $^{\mathrm{a}}$, Lillian Barros ${ }^{\mathrm{a}}$, Ana Maria Carvalho, Isabel C.F.R. Ferreira* \\ CIMO-Escola Superior Agrária, Instituto Politécnico de Bragança, Campus de Santa \\ Apolónia, 1172, 5301-855 Bragança, Portugal
}

*Corresponding author. Tel.+351 273 303219; fax +351273325405.

E-mail address: iferreira@ipb.pt (I.C.F.R. Ferreira)

${ }^{a}$ Both authors contributed equally 


\begin{abstract}
Analysis of organic acids has become increasingly important due to their role in the physiological activity of plants, and many separation methods have been developed for the simultaneous determination of these compounds in plant samples. Herein, ultra fast liquid chromatography and photodiode array detection (UFLC-PDA) was applied to the analysis of organic acids in young shoots, leaves, aerial parts and flowering shoots, as well as in flowers and fruits, of thirty five plant species, according to their traditional use. The studied plants were divided in three groups: traditionally cultivated food plants, wild edible plants and wild medicinal plants.

Most of the species were characterized for the first time. Among all the analysed species, Rumex acetosella leaves and aerial parts revealed the highest content of total organic acids. Overall, the organic acids found in the studied plant species make them suitable to be used as food additives such as antioxidants (e.g. ascorbic acid) or acidulants (e.g. citric and malic acids).
\end{abstract}

Keywords UFLC-PDA; Organic acids; Edible plants; Medicinal plants 


\section{Introduction}

Plants possess a unique richness and diversity of metabolites including organic acids. These compounds serve a variety of roles in both primary and secondary plant metabolism (Bennet-Clark 1993). Organic acids are involved in various fundamental pathways in plant metabolism and catabolism as intermediate or end products. Citric, malic, succinic, fumaric and oxalic acids play a key role in the Krebs cycle which is the central energyyielding cycle of the cell, being involved in the most important metabolic pathway of carbohydrates, lipids and proteins (Bennet-Clark 1993). Malic acid is involved in respiration and photosynthesis. This organic acid as also citric and oxalic acids have been proposed to be involved in cation transport and in processes operating in the rhizosphere, including nutrient acquisition, metal detoxification, alleviation of anaerobic stress in roots, mineral weathering and microbial attraction (Mucha et al. 2005). Organic acids are also known for their influence in the organoleptic properties of plant foods (Vaughan and Geissler 1997) and for their utility in the authenticity and quality of these matrices, including microbial stability and product consistence (Gebre et al. 1994). They are also used extensively as food additives in the manufacture of beverages, fruit and vegetable drinks and juices. The main acids used to enhance beverages are citric, malic and tartaric acids as acidulants and ascorbic acid as antioxidant (Scherer et al. 2012).

Analysis of organic acids has become increasingly important due to their role in the physiological activity of plants (Bennet-Clark 1993). Furthermore, the success in clarification of all the functions previously mentioned depends on the identification of organic acids in soil and in different parts of plants.

Many separation methods have been developed for the simultaneous determination of organic acids in plant samples such as gas chromatography (GC) (Adams et al. 1999), capillary electrophoresis (Rivasseau et al. 2006; Wang et al. 2003), ion chromatography 
(IC) (Gabriel and Kesselmeier 1999; Qiu and Jin 2002) and high-performance liquid chromatography (HPLC) (Ferreres et al. 2009; Guerra et al. 2008; Scherer et al. 2012; Veberic et al. 2009). The determination of organic acids with GC requires derivatisation because they are non-volatile, and this process requires time retarding the reproducibility of the analysis (Wang et al. 2003). HPLC has become more and more popular for analyzing certain mixtures of organic acids because of the simplicity, speed and stability of the method (Scherer et al. 2012). In a previous paper we reported the development of a different methodology for organic acids extraction from plants and their analysis using ultra fast liquid chromatography and photodiode array detection (UFLC-PDA). The method proved to be reproducible and accurate and allowed compounds separation in 8 min (Barros et al. 2012).

Herein, the application of this method was generalized to other natural matrixes, specifically plant sources. Different parts of thirty five species of food (cultivated and wild) and medicinal plants were analysed according to their recommended use.

\section{Materials and methods}

Plant species

Thirty five species of plants were obtained in Bragança (Northeast Portugal) according to their traditional use and information provided in Table 1. The studied plants were divided in three groups: cultivated food plants, wild edible plants and wild medicinal plants and in each group different parts (young shoots, leaves, aerial parts, flowering shoots, flowers and fruits) were analysed. 
All the samples were lyophilised, reduced to a fine dried powder (20 mesh) and mixed to obtain a homogenate sample.

Standards and reagents

The standards of organic acids $(\mathrm{L}(+)$-ascorbic acid; citric acid; malic acid; oxalic acid; shikinic acid; succinic acid; fumaric acid; quinic acid) were purchased from Sigma (St. Louis, MO, USA). All other chemicals and solvents were of analytical grade and purchased from common sources. Water was treated in a Milli-Q water purification system (TGI Pure Water Systems, USA).

Organic acids extraction and analysis

Samples $(\sim 2 \mathrm{~g})$ were extracted by stirring with $25 \mathrm{~mL}$ of meta-phosphoric acid $\left(25^{\circ} \mathrm{C}\right.$ at $150 \mathrm{rpm}$ ) for $45 \mathrm{~min}$ and subsequently filtered through Whatman No. 4 paper (Barros et al., 2012). Before analysis by ultra fast liquid chromatograph (UFLC) coupled to photodiode array detector (PDA), the sample was filtered through $0.2 \mu \mathrm{m}$ nylon filters. The analysis was performed using a Shimadzu 20A series UFLC (Shimadzu Coperation). Separation was achieved on a SphereClone (Phenomenex) reverse phase $C_{18}$ column $(5 \mu \mathrm{m}, 250 \mathrm{~mm} \times$ 4.6 $\mathrm{mm}$ i.d) thermostatted at $35^{\circ} \mathrm{C}$. The elution was performed with sulphuric acid 3.6 $\mathrm{mM}$ using a flow rate of $0.8 \mathrm{~mL} / \mathrm{min}$. Detection was carried out in a PDA, using $215 \mathrm{~nm}$ and $245 \mathrm{~nm}$ (for ascorbic acid) as preferred wavelengths. The organic acids found were quantified by comparison of the area of their peaks recorded at $215 \mathrm{~nm}$ or $245 \mathrm{~nm}$ (for ascorbic acid) with calibration curves obtained from commercial standards of each compound. The results were expressed in mg per g of dry weight (dw).

Statistical analysis 
Organic acids extraction was performed in duplicate and each sample was injected three times in UFLC-PAD. The results are expressed as mean values \pm standard deviation (SD). The differences between mushroom species were analyzed using one-way analysis of variance (ANOVA) followed by Tukey's HSD Test with $\alpha=0.05$. This analysis was carried out using SPSS v. 18.0 program.

\section{Results and discussion}

The analysed samples have been extensively studied by our research group, considering their chemical composition and antioxidant properties, due to their widely uses as food and/or medicinal plants. The studied samples included different parts of cultivated and wild food plants, as also wild medicinal plants (Table 1). All of them presented malic and citric acids; some samples also revealed the presence of oxalic, quinic, shikimic, ascorbic, succinic and fumaric acids. A profile obtained at $215 \mathrm{~nm}$ can be observed in Figure 1.

Table 2 shows the composition of organic acids in cultivated edible plants (flowers and fruits). Two traditional cultivated vegetables highly consumed in Northern Portuguese region were analysed; Brassica napus var napus (rape) presented higher total (90 mg/g dw) and individual organic compounds than Brassica oleraceae var costata ("tronchuda" cabbage) with exception of oxalic and citric acids. The latter species presented citric acid as most abundant organic acid, which is in agreement with a previous study reported by Ferreres et al. 2009. The mentioned organic acid is an important multifunctional organic acid with a broad range of versatile uses in household and industrial applications; there is a great worldwide demand for citric acid consumption due to its low toxicity, mainly being used as acidulant in pharmaceutical and food industries (Anastassiadis et al. 2008).

Four common farmer' varieties of tomato (Lycopersicon esculentum) widely cultivated in rural communities from Miranda do Douro (Trás-os-Montes, Northeastern Portugal) were 
analysed: "amarelo" (yellow tomato), "batateiro" (round tomato), "comprido" (long tomato) and "coração-de-boi" (heart tomato). The four samples revealed the same amount of oxalic acid. "Batateiro" and "coração-de-boi" varieties revealed the highest contents in organic acids (168 and $163 \mathrm{mg} / \mathrm{g} \mathrm{dw}$, respectively), with the important contribution of citric acid. This compound has been reported as the main organic acid in other tomato varieties (Suaréz et al. 2008). The mentioned two samples also gave the highest content in ascorbic acid (3 mg/g dw). In humans, principal role of this compound is to scavenge reactive oxygen species, due to its antioxidant capacity, and to serve as co-factor of many enzymes; a deficiency of ascorbic acid is traditionally linked to human diseases such as scurvy (Cruz-Rus et al. 2012).

The composition of organic acids in wild edible plants (young shoots, leaves and aerial parts, flowers and fruits) is given in Table 3. Among plants consumed as young shoots, three edible wild greens widely consumed were studied: Asparagus acutifolius (wild asparagus), Bryonia dioica (white bryony) and Tamus communis (black bryony). B. dioica showed the highest content of organic acids $(148 \mathrm{mg} / \mathrm{g} \mathrm{dw})$ with the significant contribution of malic acid (125 mg/g dw). This compound occurs naturally in all fruits and many vegetables; it contributes to the pleasantly sour taste of fruits, and it is used as a food additive (Barros et al. 2012). Shikimic, succinic and fumaric acids were only found in $T$. communis, A. acutifolius and B. dioica samples, respectively. These results were also observed by other authors in $T$. communis and B. dioica samples from Spain (SánchezMata et al. 2012).

Leaves and aerial parts of other four wild greens traditionally consumed were also analysed: Borago officinalis (borage), Montia Fontana (water-blinks), Rorippa nasturtiumaquaticum (water-cress) and Rumex acetosella (sheep sorrel). The latter species gave the highest content of organic acids $(277 \mathrm{mg} / \mathrm{g} \mathrm{dw})$ with the main contribution of quinic acid 
(238 $\mathrm{mg} / \mathrm{g} \mathrm{dw}$ ), which is a versatile chiral starting material for the synthesis of new pharmaceuticals (Barros et al. 2012). Ascorbic acid was only found in the mentioned species. Nevertheless, it should be noticed that ascorbic acid presents a very low stability through storage time due to oxidative processes and, therefore, the levels of this compound could be underestimated. There are available on literature reports regarding organic acids in other Rumex species such as R. induratus (Guerra et al. 2008), R. papilaris and $R$. pulcher (Sánchez-Mata et al. 2012), showing a different profile from $R$. acetosella. Fumaric acid was found in higher amounts in borage sample, being reported as an important antioxidant and antimicrobial compound (Barros et al. 2012).

Flowers of three widespread Mediterranean perennial herbs traditionally used for medicinal purposes and seasoning were characterized: Foeniculum vulgare (fennel), Origanum vulgare (origano) and Thymus mastichina (thyme). F. vulgare showed the highest content of organic acids $(127 \mathrm{mg} / \mathrm{g} \mathrm{dw})$ with the main contribution of malic acid $(63 \mathrm{mg} / \mathrm{g} \mathrm{dw})$. The profile observed in this sample is different from the one described by Sánchez-Mata et al. (2012) in a sample from Spain, in which oxalic acid is reported as the main organic acid. It should be highlighted that calcium oxalate is the most common component of kidney stones and can be directly absorbed by the gut in spite of its insolubility (Ribeiro et al. 2008). As far as we know, there are not available reports on organic acids of the two mentioned Lamiaceae.

Regarding fruits, four wild species were analysed: Arbutus unedo (strawberry-tree), Crataegus monogyna (common hawthorn), Prunus spinosa (blackthorn) and Rosa canina (dog rose), being $P$. spinosa sample the one presenting the highest levels of organic acids (96 mg/g dw) with the significant contribution of malic acid $(93 \mathrm{mg} / \mathrm{g} \mathrm{dw})$. This observation is in agreement with the results reported by Özcan (2008) in a sample from Turkey. Similarly to the observed data in the present study, Bozan et al. (1998) described 
citric acid as the main organic acid in $R$. canina fruits. Otherwise, the profile described for A. unedo fruits from Spain (Ruiz-Rodríguez et al. 2011) is different. Considering organic acids in C. monogyna fruits, no reports were found.

The composition of organic acids in flowers and flowering shoots of fourteen wild medicinal plants is given in Table 4, that include i) four common Mediterranean shrubs from Fabaceae family (tribe Genisteae) that have been used for medicinal purposes and seasoning in the northeastern Portuguese region: Cytisus multiflorus (white Spanish broom), C. scoparius (common broom), C. striatus (Portuguese broom) and Pterospartum tridentatum; ii) two samples native throughout most of Europe and Asia that have long been used in the Iberian Peninsula as important medicinal plants: Filipendula ulmaria (meadowsweet) and Sambucus nigra (elder); iii) six medicinal plants traditionally used in the northeastern region of Portugal: Centaurea paniculata (starthistles), Crataegus monogyna (common hawthorn), Helichrysum stoechas (shrubby everlasting), Rosa micrantha (sweet-briar), Rubus ulmifollius (elm-leaved blackberry) and Trifolium angustifolium (narrow clover); and v) two samples widely used in Mediterranean and European traditional medicine and ethnoveterinary: Malva sylvestris (common mallow) and Tuberaria lignosa (similar to spotted rockrose).

S. nigra sample presented the highest concentration of total organic acids $(159 \mathrm{mg} / \mathrm{g} \mathrm{dw})$ due to the main contribution of citric acid $(97 \mathrm{mg} / \mathrm{g} \mathrm{dw})$, which is in agreement with the results reported in flowers from Austria (Veberic et al., 2009) and fruits (Karovicová et al., 1990) of this species. For the other species, no reports were found.

The fruits of Rosa micrantha, highly appreciated for their health and cosmetic properties, showed citric, quinic, ascorbic, malic and oxalic acids with a total content of $54 \mathrm{mg} / \mathrm{g} \mathrm{dw}$ (Table 4). 


\section{Conclusion}

The organic acid profiles of thirty five food and medicinal plant species was obtained by UFLC-PDA, being detected and quantified oxalic, quinic, malic, shikimic, ascorbic, citric, succinic and fumaric acids in different amounts, according to species. Among all the analysed species, Rumex acetosella leaves and aerial parts revealed the highest content of total organic acids; otherwise, Pterospartum tridentatum presented the lowest concentration $(8 \mathrm{mg} / \mathrm{g} \mathrm{dw})$.

Most of the species were characterized for the first time; for the others, some differences were found in the results reported herein and the ones described by other authors. This could be due to numerous factors such as the different extraction and/or analysis methodology and different analysis conditions (e.g analysis carried out in fresh or dried material), as also environmental conditions related to samples collection. The organic acids found in the studied plant species make them suitable to be used as food additives such as antioxidants (e.g. ascorbic acid) or acidulants (e.g. citric and malic acids). Furthermore, these compounds can be useful in the authenticity and quality of the plant sources.

Acknowledgements The authors are grateful to Fundação para a Ciência e a Tecnologia (FCT, Portugal) and COMPETE/QREN/EU for financial support to CIMO (strategic project PEst-OE/AGR/UI0690/2011). L. Barros also thanks to FCT, POPH-QREN and FSE for her grant (SFRH/BPD/4609/2008).

\section{References}

Adams MA, Chen ZL, Landman P, Colmer TD (1999) Simultaneous determination by capillary gas chromatography of organic acids, sugars, and sugar alcohols in plant tissue extracts as their trimethylsilyl derivatives. Anal Biochem 266:77-84 
Anastassiadis S, Morgunov IG, Kamzolova SV, Finogenova TV (2008) Citric acid production patent review. Recent Pat Biotechnol 2:107-123

Barros L, Heleno SA, Carvalho AM, Ferreira ICFR (2009) Systematic evaluation of the antioxidant potential of different parts of Foeniculum vulgare Mill. from Portugal. Food Chem Toxicol 47:2458-2464

Barros L, Carvalho AM, Morais JS, Ferreira ICFR (2010a) Strawberry-tree, blackthorn and rose fruits: Detailed characterization in nutrients and phytochemicals with antioxidant properties. Food Chem 120:247-254

Barros L, Oliveira S, Carvalho AM, Ferreira ICFR (2010b) In vitro antioxidant properties and characterization in nutrients and phytochemicals of six medicinal plants from the Portuguese folk medicine. Ind Crops Prod 32:572-579

Barros L, Heleno SA, Carvalho AM, Ferreira ICFR (2010c) Lamiaceae often used in Portuguese folk medicine as a source of powerful antioxidants: Vitamins and phenolics. LWT - Food Sci Tech 43:544-550

Barros L, Carvalho AM, Ferreira ICFR (2010d) Leaves, flowers, immature fruits and leafy flowered stems of Malva sylvestris: A comparative study of the nutraceutical potential and composition. Food Chem Toxicol 48:1466-1472

Barros L, Carvalho AM, Ferreira ICFR (2011a) Comparing the Composition and Bioactivity of Crataegus Monogyna Flowers and Fruits used in Folk Medicine. Phytochem Anal 22:181-188

Barros L, Cabrita L, Vilas-Boas M, Carvalho AM, Ferreira ICFR (2011b) Chemical, biochemical and electrochemical assays to evaluate phytochemicals and antioxidant activity of wild plants. Food Chem 127:1600-1608 
Barros L, Carvalho AM, Ferreira ICFR (2011c) Exotic fruits as a source of important phytochemicals: Improving the traditional use of Rosa canina fruits in Portugal. Food Res Inter 44 (2011) 2233-2236

Barros L, Pereira C, Ferreira ICFR (2012) Optimized analysis of organic acids in edible mushrooms from Portugal by ultra fast liquid chromatography and photodiode array detection. Food Anal Method. DOI: 10.1007/s12161-012-9443-1.

Batista C, Barros L, Carvalho AM, Ferreira ICFR (2011) Nutritional and nutraceutical potential of rape (Brassica napus L. var. napus) and "tronchuda" cabbage (Brassica oleraceae L. var. costata) inflorescences. Food Chem Toxicol 49:1208-1214

Bennet-Clark TA (1993) The role of the organic acids in plant metabolism. Part I. New Phytol 32:37

Bozan B, Sagdullaev BT, Kzar M, Aripov KhN, Baser KHC (1998) Comparison of ascorbic and citric acid contents in Rosa canina L. fruit growing in the central Asian region. Chem Nat Comp 34:687-689

Cruz-Rus E, Amaya I, Valpuesta V (2012) The challenge of increasing vitamin C content in plant foods. Biotechnol J. 7:1110-1121

Ferreres F, Fernandes F, Sousa C, Valentão P, Pereira JA, Andrade PB (2009) Metabolic and bioactivity insights into Brassica oleracea var. acephala. J Agric Food Chem $57: 8884-8892$

Gabriel J, Kesselmeier (1999) Apoplastic solute concentrations of organic acids and mineral nutrients in the leaves of several Fagaceae. Plant Cell Physiol 40:604-612

Gebre GM, Kuhns MR, Brandle JR (1994) Organic solute accumulation and dehydration tolerance in three water-stresses Populus deltoids clones. Tree Physiol 14:575-587 
Guerra L, Pereira C, Andrade PB, Rodrigues MA, Ferreres F, Pinho PG, Seabra RM, Valentão P (2008) Targeted metabolite analysis and antioxidante potential of Rumex induratus. J Agric Food Chem 56:8184-8194

Guimarães R, Barros L, Carvalho A, Ferreira ICFR (2010) Studies on chemical constituents and bioactivity of Rosa micrantha: An alternative antioxidants source for food, pharmaceutical, or cosmetic applications. J Agric Food Chem 58:6277-6284

Karovicová J, Polonsky J, Príbela A (1990) Composition of organic acids of Sambucus nigra and Sambucus ebulus. Nahrung 34:665-667

Martins D, Barros L, Carvalho AM, Ferreira ICFR (2011) Nutritional and in vitro antioxidant properties of edible wild greens in Iberian Peninsula traditional diet. Food Chem 125:488-494

Mucha AP, Almeida CMR, Bordalo AA, Vasconcelos MTSD (2005) Exudation of organic acids by a marsh plant and implications on trace metal availability in the rhizosphere of estuarine sediments. Est. Coast. Shelf Sci 65:191-198

Özcan T (2008) Some vitamin and organic acid contents in the fruits of Prunus spinosa L. subsp. Dasyphulla (Schur) domin from Europe-in-Turkey. IUFS J Biol 67:105-114

Pereira C, Barros L, Carvalho AM, Ferreira ICFR (2011) Nutritional composition and bioactive properties of commonly consumed wild greens: Potential sources for new trends in modern diets. Food Res Inter 44:2634-2640

Pinela J, Barros L, Carvalho AM, Ferreira ICFR (2011) Influence of the drying method in the antioxidant potential and chemical composition of four shrubby flowering plants from the tribe Genisteae (Fabaceae). Food Chem Toxicol 49:2983-2989

Pinela J, Barros L, Carvalho AM, Ferreira ICFR (2012a) Nutritional composition and antioxidant activity of four tomato (Lycopersicon esculentum L.) farmer' varieties in Northeastern Portugal homegardens. Food Chem Toxicol 50:829-834 
Pinela J, Barros L, Dueñas M, Carvalho AM, Santos-Buelga C, Ferreira ICFR (2012b) Antioxidant activity, ascorbic acid, phenolic compounds and sugars of wild and commercial Tuberaria lignosa samples: Effects of drying and oral preparation methods. Food Chem 135:1028-1035

Qiu J, Jin X (2002) Development and optimization of organic acid analysis in tobacco with ion chromatography and suppressed conductivity detection. J Chromatogr A 950:81-88

Ribeiro B, Andrade PB, Baptista P, Barros L, Ferreira ICFR, Seabra RM, Valentão P (2008) Leucopaxillus giganteus mycelium: Effect of nitrogen source on organic acids and alkaloids. J Agric Food Chem 56:4769-4774

Rivasseau C, Boisson A-M, Mongélard G, Couram G, Bastien O, Bligny R (2006) Rapid analysis of organic acids in plant extracts by capillary electrophoresis with indirect UV detection. Directed metabolic analyses during metal stress. J Chromatogr A 129:283290

Ruiz-Rodríguez B-M, Morales P, Fernández-Ruiz V, Sánchez-Mata M-C, Cámara M, Díez-Marqués C, Pardo-de-Santayana, Molina M, Tardio J (2011) Valorization of wild strawberry-tree fruits (Arbutus unedo L.) though nutritional assessment and natural production data. Food Res Int 44:1244-1253

Sánchez-Mata MC, Loera RDC, Morales P, Fernández-Ruiz V, Cámara C, Marqués D, Pardo-de-Santayana M, Tardio J (2012) Wild vegetables of the Mediterranean area as valuable sources of bioactive compounds. Genet Resour Crop Evol 59:431-443

Scherer R, Rybca ACP, Ballus CA, Meinhart AD, Filho JT, Godoy HT (2012) Validation of a HPLC method for simultaneous determination of main organic acids in fruits and juices. Food Chem 135:150-154

Suaréz MH, Rodríguez ER, Romero CD (2008) Analysis of organic acid content in cultivars of tomato harvested in Tenerife. Eur Food Res Technol 226:423-435 
Vaughan JG, Geissler CA (1997) The New Oxford Book of Food Plants, Oxford University Press: New York, p 196

Veberic R, Jakopic J, Stampar F, Schmitzer V (2009) European elderberry (Sambucus nigra L.) rich in sugars, organic acids, anthocyanins and selected polyphenols. Food Chem 114:511-515

Wang M, Qu F, Shan X-Q, Lin J-M (2003) Development and optimization of a method for the analysis of low-molecular-mass organic acids in plants by capillary electrophoresis with indirect UV detection. J Chromatogr 989:285-292 
Table 1. Information about the analysed species.

\begin{tabular}{|c|c|c|c|}
\hline Scientific name & Collection year & Analysed part & Reference $^{*}$ \\
\hline Arbutus unedo L: & 2008 & Fruits & Barros et al. 2010a \\
\hline Asparagus acutifolius L. & 2009 & Young shoots & Martins et al. 2011 \\
\hline Borago officinalis $\mathrm{L}$. & 2010 & Leaves and aerial parts & Pereira et al. 2011 \\
\hline Brassica napus L.var napus & 2009 & Flowers & Batista et al. 2011 \\
\hline Brassica oleraceae L. var costata & 2009 & Flowers & Batista et al. 2011 \\
\hline Bryonia dioica Jacq. & 2009 & Young shoots & Martins et al. 2011 \\
\hline Centaurea paniculata L. & 2009 & Flowers and flowering shoots & Barros et al. 2010b \\
\hline Crataegus monogyna Jacq. & 2009 & $\begin{array}{l}\text { Flowers and flowering shoots } \\
\text { Fruits }\end{array}$ & Barros et al. 2011a \\
\hline Cytisus multiflorus (L'Hér.) Sweet & 2010 & Flowers and flowering shoots & Pinela., et al. 2011 \\
\hline Cytisus scoparius (L.) Link & 2010 & Flowers and flowering shoots & Pinela., et al. 2011 \\
\hline Cytisus striatus (Hill) Rothm. & 2010 & Flowers and flowering shoots & Pinela., et al. 2011 \\
\hline Filipendula ulmaria (L.) Maxim. & 2009 & Flowers and flowering shoots & Barros et al. 2011b \\
\hline Foeniculum vulgare $\mathrm{L}$. & 2009 & Flowers & Barros et al. 2009 \\
\hline Helichrysum stoechas (L.) Moench & 2009 & Flowers and flowering shoots & Barros et al. 2010b \\
\hline Lycopersicon esculentum L. ("amarelo") & 2011 & Fruits & Pinela et al. 2012a \\
\hline Lycopersicon esculentum L. ("batateiro") & 2011 & Fruits & Pinela et al. 2012a \\
\hline Lycopersicon esculentum L. (“chucha") & 2011 & Fruits & Pinela et al. 2012a \\
\hline $\begin{array}{l}\text { Lycopersicon esculentum L. ("coração-de- } \\
\text { boi") }\end{array}$ & 2011 & Fruits & Pinela et al. 2012a \\
\hline Malva sylvestris $\mathrm{L}$. & 2009 & Flowers and flowering shoots & Barros et al. 2010d \\
\hline Montia fontana $\mathrm{L}$. & 2010 & Leaves and aerial parts & Pereira et al. 2011 \\
\hline Origanum vulgare L. & 2008 & Flowerss & Barros et al. 2010c \\
\hline Prunus spinosa L. & 2008 & Fruits & Barros et al. 2010a \\
\hline Pterospartum tridentatum (L.) Willk. & 2010 & Flowers and flowering shoots & Pinela., et al. 2012 \\
\hline Rorippa nasturium-aquaticum (L.) Hayek & 2010 & Leaves and aerial parts & Pereira et al. 2011 \\
\hline Rosa canina $\mathrm{L}$. & 2009 & Fruits & Barros et al. 2011c \\
\hline Rosa micrantha Borrer ex Sm. & 2009 & $\begin{array}{l}\text { Flowers and flowering shoots } \\
\text { Fruits }\end{array}$ & Guimarães et al. 2010 \\
\hline Rubus ulmifolius Schott & 2009 & Flowers and flowering shoots & Barros et al. 2010b \\
\hline Rumex acetosella $\mathrm{L}$. & 2010 & Leaves and aerial parts & Pereira et al. 2011 \\
\hline Sambucus nigra L. & 2009 & Flowers and flowering shoots & Barros et al. 2011b \\
\hline Tamus communis $\mathrm{L}$ & 2009 & Young shoots & Martins et al. 2011 \\
\hline Thymus mastichina L & 2008 & Flowers & Barros et al. 2010c \\
\hline Trifolium angustifolium L. & 2009 & Flowers and flowering shoots & Barros et al. 2010b \\
\hline Tuberaria lignosa (Sweet) Samp. & 2011 & Flowers and flowering shoots & Pinela et al. 2012b \\
\hline
\end{tabular}

${ }^{*}$ These references provide information about chemical composition and/or antioxidant properties of the plant species, and report the first time in which they were collected and studied by our research group. 
Table 2. Organic acids composition (mg/g of dry weight) of the studied cultivated edible plants (mean $\pm \mathrm{SD})$.

\begin{tabular}{|c|c|c|c|c|c|c|c|c|}
\hline Analysed part & Plant species & Oxalic acid & Quinic acid & Malic acid & Ascorbic acid & Citric acid & Fumaric acid & Total \\
\hline \multirow{2}{*}{ Flowers } & Brassica oleraceae var costata & $3.34 \pm 0.07^{\mathrm{a}}$ & $12.05 \pm 0.07^{\mathrm{b}}$ & $7.93 \pm 1.45^{b}$ & $0.35 \pm 0.00^{\mathrm{b}}$ & $50.48 \pm 0.98^{\mathrm{a}}$ & $0.43 \pm 0.01^{\mathrm{b}}$ & $74.57 \pm 0.46^{\mathrm{b}}$ \\
\hline & Brassica napus var napus & nd & $27.90 \pm 1.03^{\mathrm{a}}$ & $20.55 \pm 2.13^{\mathrm{a}}$ & $1.00 \pm 0.03^{\mathrm{a}}$ & $39.96 \pm 1.87^{\mathrm{b}}$ & $0.52 \pm 0.01^{\mathrm{a}}$ & $89.94 \pm 1.33^{\mathrm{a}}$ \\
\hline \multirow{4}{*}{ Fruits } & Lycopersicon esculentum ("amarelo") & $0.76 \pm 0.00^{\mathrm{a}}$ & $9.27 \pm 0.46^{b}$ & $17.22 \pm 0.28^{\mathrm{a}}$ & $2.55 \pm 0.02^{\mathrm{c}}$ & $88.84 \pm 0.90^{\mathrm{c}}$ & nd & $118.63 \pm 0.15^{b}$ \\
\hline & Lycopersicon esculentum ("batateiro") & $0.81 \pm 0.33^{\mathrm{a}}$ & $5.28 \pm 0.25^{\mathrm{c}}$ & $6.14 \pm 0.39^{b}$ & $3.35 \pm 0.07^{\mathrm{a}}$ & $152.90 \pm 13.99^{\mathrm{a}}$ & nd & $168.47 \pm 7.62^{\mathrm{a}}$ \\
\hline & Lycopersicon esculentum ("chucha") & $0.97 \pm 0.10^{\mathrm{a}}$ & $9.92 \pm 0.58^{\mathrm{b}}$ & $0.35 \pm 0.04^{\mathrm{c}}$ & $3.07 \pm 0.08^{b}$ & $64.52 \pm 0.37^{\mathrm{d}}$ & nd & $78.82 \pm 0.19^{\mathrm{c}}$ \\
\hline & Lycopersicon esculentum (“coração de boi”) & $0.86 \pm 0.12^{\mathrm{a}}$ & $12.02 \pm 1.19^{\mathrm{a}}$ & $5.26 \pm 1.64^{\mathrm{b}}$ & $3.22 \pm 0.10^{\mathrm{a}}$ & $141.32 \pm 18.30^{\mathrm{b}}$ & nd & $162.68 \pm 3.89^{\mathrm{a}}$ \\
\hline
\end{tabular}

nd- not detected. In each column, different letters mean significant differences among samples $(\mathrm{p}<0.05)$. 
Table 3. Organic acids composition (mg/g of dry weight) of the studied wild edible plants (mean \pm SD).

\begin{tabular}{|c|c|c|c|c|c|c|c|c|c|c|}
\hline Analysed part & Plant species & Oxalic acid & Quinic acid & Malic acid & Shikimic acid & Ascorbic acid & Citric acid & Succinic acid & Fumaric acid & Total \\
\hline \multirow{3}{*}{ Young shoots } & Asparagus acutifolius & $6.06 \pm 0.35^{\mathrm{b}}$ & $11.94 \pm 0.24^{b}$ & $1.20 \pm 0.22^{b}$ & nd & $1.66 \pm 0.00^{\mathrm{a}}$ & $26.77 \pm 0.14^{\mathrm{a}}$ & $7.10 \pm 0.20^{\mathrm{a}}$ & nd & $54.73 \pm 0.31^{b}$ \\
\hline & Bryonia dioica & nd & $13.44 \pm 0.59^{\mathrm{a}}$ & $125.52 \pm 1.78^{\mathrm{a}}$ & nd & $0.25 \pm 0.00^{\mathrm{b}}$ & $7.93 \pm 0.25^{\mathrm{b}}$ & nd & $0.54 \pm 0.00^{\mathrm{a}}$ & $147.68 \pm 2.13^{\mathrm{a}}$ \\
\hline & Tamus communis & $9.70 \pm 1.42^{\mathrm{a}}$ & nd & $4.67 \pm 0.04^{\mathrm{b}}$ & $2.06 \pm 0.00^{\mathrm{a}}$ & $1.55 \pm 0.14^{\mathrm{a}}$ & $27.14 \pm 1.52^{\mathrm{a}}$ & nd & nd & $45.12 \pm 2.66^{\mathrm{c}}$ \\
\hline \multirow{4}{*}{ Leaves and aerial parts } & Borago officinalis & $42.87 \pm 0.31^{\mathrm{a}}$ & nd & $2.58 \pm 0.29^{c}$ & $0.12 \pm 0.00^{\mathrm{b}}$ & nd & $7.12 \pm 0.31^{\mathrm{c}}$ & $6.25 \pm 0.16^{\mathrm{a}}$ & $23.01 \pm 0.36^{\mathrm{a}}$ & $81.93 \pm 0.80^{\mathrm{c}}$ \\
\hline & Montia fontana & $35.28 \pm 0.16^{\mathrm{c}}$ & $9.82 \pm 1.65^{\mathrm{b}}$ & $3.14 \pm 0.01^{\mathrm{c}}$ & nd & nd & $22.19 \pm 0.41^{\mathrm{b}}$ & nd & nd & $70.42 \pm 1.07^{\mathrm{d}}$ \\
\hline & Rorippa nasturium-aquaticum & $37.12 \pm 0.79^{\mathrm{b}}$ & $3.52 \pm 1.15^{\mathrm{c}}$ & $11.70 \pm 0.51^{\mathrm{b}}$ & $0.15 \pm 0.00^{\mathrm{a}}$ & nd & $56.32 \pm 3.41^{\mathrm{a}}$ & $5.17 \pm 0.08^{\mathrm{b}}$ & $0.14 \pm 0.02^{\mathrm{b}}$ & $114.12 \pm 0.90^{\mathrm{b}}$ \\
\hline & Rumex acetosella & $12.53 \pm 0.11^{\mathrm{d}}$ & $238.01 \pm 2.67^{\mathrm{a}}$ & $15.65 \pm 0.20^{\mathrm{a}}$ & nd & $6.61 \pm 0.01^{\mathrm{a}}$ & $2.43 \pm 0.15^{\mathrm{d}}$ & $1.74 \pm 0.06^{\mathrm{c}}$ & $0.04 \pm 0.00^{\mathrm{b}}$ & $277.00 \pm 2.78^{\mathrm{a}}$ \\
\hline \multirow{3}{*}{ Flowers } & Foeniculum vulgare & $23.31 \pm 0.38^{\mathrm{a}}$ & $16.90 \pm 0.04^{b}$ & $63.27 \pm 0.27^{\mathrm{a}}$ & $0.09 \pm 0.06^{b}$ & nd & $23.33 \pm 0.20^{\mathrm{a}}$ & nd & $0.51 \pm 0.02^{\mathrm{a}}$ & $127.41 \pm 0.88^{\mathrm{a}}$ \\
\hline & Origanum vulgare & $3.16 \pm 0.01^{\mathrm{c}}$ & $23.03 \pm 0.71^{\mathrm{a}}$ & $5.08 \pm 0.06^{\mathrm{c}}$ & $0.22 \pm 0.02^{\mathrm{a}}$ & nd & $13.72 \pm 0.08^{\mathrm{b}}$ & nd & nd & $45.21 \pm 0.86^{\mathrm{b}}$ \\
\hline & Thymus mastichina & $4.70 \pm 0.42^{\mathrm{b}}$ & $11.24 \pm 0.05^{\mathrm{c}}$ & $6.24 \pm 0.21^{\mathrm{b}}$ & nd & $\operatorname{tr}$ & $6.72 \pm 1.77^{\mathrm{c}}$ & nd & $0.08 \pm 0.02^{\mathrm{b}}$ & $28.97 \pm 2.37^{\mathrm{c}}$ \\
\hline \multirow{4}{*}{ Fruits } & Arbutus unedo & $2.10 \pm 0.11^{b}$ & $53.93 \pm 1.16^{\mathrm{a}}$ & $13.71 \pm 0.71^{\mathrm{c}}$ & nd & $4.81 \pm 0.02^{\mathrm{a}}$ & $0.67 \pm 0.13^{b}$ & nd & $0.01 \pm 0.00^{\mathrm{a}}$ & $75.22 \pm 1.88^{c}$ \\
\hline & Crataegus monogyna & $2.10 \pm 0.12^{\mathrm{b}}$ & $8.03 \pm 0.01^{\mathrm{c}}$ & $15.11 \pm 0.10^{\mathrm{b}}$ & $0.23 \pm 0.00^{\mathrm{a}}$ & nd & $0.73 \pm 0.03^{\mathrm{c}}$ & nd & nd & $74.19 \pm 0.93^{c}$ \\
\hline & Prunus spinosa & $1.18 \pm 0.05^{\mathrm{c}}$ & $0.38 \pm 0.13^{\mathrm{d}}$ & $93.16 \pm 0.06^{\mathrm{a}}$ & $0.06 \pm 0.01^{\mathrm{b}}$ & $0.04 \pm 0.00^{\mathrm{c}}$ & $0.42 \pm 0.03^{\mathrm{c}}$ & $0.32 \pm 0.01^{\mathrm{a}}$ & $0.01 \pm 0.00^{\mathrm{a}}$ & $95.57 \pm 0.10^{\mathrm{a}}$ \\
\hline & Rosa canina & $2.91 \pm 0.36^{\mathrm{a}}$ & $14.59 \pm 0.07^{\mathrm{b}}$ & $6.15 \pm 0.09^{d}$ & nd & $3.71 \pm 0.02^{\mathrm{b}}$ & $60.94 \pm 1.76^{\mathrm{a}}$ & nd & $0.01 \pm 0.00^{\mathrm{a}}$ & $88.31 \pm 1.97^{\mathrm{b}}$ \\
\hline
\end{tabular}

nd- not detected. In each column, different letters mean significant differences among samples $(\mathrm{p}<0.05)$. 
Table 4. Organic acids composition ( $\mathrm{mg} / \mathrm{g}$ of dry weight) of the studied wild medicinal plants (mean \pm SD).

\begin{tabular}{|c|c|c|c|c|c|c|c|c|c|c|}
\hline Analysed part & Plant species & Oxalic acid & Quinic acid & Malic acid & Shikimic acid & Ascorbic acid & Citric acid & Succinic acid & Fumaric acid & Total \\
\hline & Centaurea paniculata & $2.83 \pm 0.04^{\mathrm{e}}$ & $18.26 \pm 0.68^{\mathrm{d}}$ & $4.14 \pm 0.13^{g}$ & $1.29 \pm 0.08^{b}$ & nd & $10.29 \pm 0.39^{\mathrm{cbd}}$ & $5.30 \pm 0.23^{b}$ & nd & $42.12 \pm 1.08^{\mathrm{d}}$ \\
\hline & Crataegus monogyna & $9.15 \pm 0.88^{\mathrm{dc}}$ & $30.83 \pm 0.93^{\mathrm{b}}$ & $20.46 \pm 0.45^{\mathrm{a}}$ & nd & $2.14 \pm 0.21^{\mathrm{a}}$ & $8.33 \pm 0.07^{\mathrm{ced}}$ & $3.28 \pm 0.15^{\mathrm{c}}$ & nd & $74.19 \pm 0.93^{\mathrm{b}}$ \\
\hline & Cytisus multiflorus & $2.60 \pm 0.00^{\mathrm{e}}$ & $11.67 \pm 0.68^{\mathrm{e}}$ & $2.54 \pm 0.19^{\mathrm{h}}$ & nd & $0.19 \pm 0.01^{\mathrm{ed}}$ & $1.89 \pm 0.13^{\mathrm{hg}}$ & $\operatorname{tr}^{\mathrm{f}}$ & $0.08 \pm 0.00^{\text {ed }}$ & $19.03 \pm 1.09^{\mathrm{f}}$ \\
\hline & Cytisus scoparius & $2.60 \pm 0.27^{\mathrm{e}}$ & $5.55 \pm 0.43^{\mathrm{g}}$ & $5.20 \pm 0.27^{\mathrm{f}}$ & nd & $0.07 \pm 0.02^{\mathrm{efg}}$ & $\operatorname{tr}^{\mathrm{h}}$ & nd & $0.05 \pm 0.00^{\mathrm{f}}$ & $13.47 \pm 0.45^{\mathrm{gf}}$ \\
\hline & Cytisus striatus & $2.91 \pm 0.21^{\mathrm{e}}$ & $3.06 \pm 0.02^{\mathrm{h}}$ & $10.66 \pm 0.46^{\mathrm{c}}$ & nd & $0.08 \pm 0.01^{\mathrm{efg}}$ & $1.49 \pm 0.62^{\mathrm{hg}}$ & $2.02 \pm 0.47^{\mathrm{d}}$ & $0.06 \pm 0.00^{\mathrm{ef}}$ & $20.27 \pm 0.81^{\mathrm{f}}$ \\
\hline & Filipendula ulmária & $9.81 \pm 0.39^{\mathrm{bac}}$ & $0.16 \pm 0.03^{\mathrm{ij}}$ & $8.23 \pm 0.53^{\mathrm{ed}}$ & $1.01 \pm 0.01^{\mathrm{c}}$ & $1.55 \pm 0.08^{\mathrm{c}}$ & $7.97 \pm 1.60^{\mathrm{ced}}$ & nd & $0.28 \pm 0.04^{\mathrm{b}}$ & $29.00 \pm 2.46^{\mathrm{e}}$ \\
\hline Flowers and & Helichrysum stoechas & $2.10 \pm 0.07^{\mathrm{e}}$ & $12.99 \pm 0.43^{\mathrm{e}}$ & $9.14 \pm 0.36^{\mathrm{d}}$ & $0.09 \pm 0.00^{\mathrm{e}}$ & $0.01 \pm 0.00^{\mathrm{g}}$ & $12.35 \pm 0.46^{\mathrm{b}}$ & $2.19 \pm 0.17^{\mathrm{d}}$ & $0.04 \pm 0.01^{\mathrm{gf}}$ & $38.90 \pm 0.57^{\mathrm{d}}$ \\
\hline \multirow[t]{7}{*}{ flowering shoots } & Malva sylvestris & $8.14 \pm 0.52^{\mathrm{dc}}$ & $\operatorname{tr}^{\mathrm{j}}$ & $3.79 \pm 0.10^{\mathrm{g}}$ & nd & $0.27 \pm 0.00^{\mathrm{d}}$ & $4.86 \pm 1.11^{\mathrm{feg}}$ & nd & $3.43 \pm 0.01^{\mathrm{a}}$ & $20.50 \pm 1.54^{\mathrm{f}}$ \\
\hline & Pterospartum tridentatum & $1.44 \pm 0.35^{\mathrm{e}}$ & $1.77 \pm 0.22^{\text {ih }}$ & $1.27 \pm 0.10^{\mathrm{i}}$ & $0.34 \pm 0.01^{\mathrm{d}}$ & nd & $2.83 \pm 0.23^{\text {hg }}$ & $0.43 \pm 0.23^{\mathrm{e}}$ & $0.01 \pm 0.00^{\mathrm{h}}$ & $8.10 \pm 1.48^{\mathrm{g}}$ \\
\hline & Rosa micrantha & $9.62 \pm 0.55^{\mathrm{bc}}$ & $40.16 \pm 0.53^{\mathrm{a}}$ & $12.36 \pm 0.65^{\mathrm{b}}$ & $2.08 \pm 0.40^{\mathrm{a}}$ & nd & $7.14 \pm 0.70^{\mathrm{fed}}$ & nd & $0.11 \pm 0.02^{\mathrm{d}}$ & $71.47 \pm 1.75^{\mathrm{b}}$ \\
\hline & Rubus ulmifolius & $4.65 \pm 0.35^{\text {ed }}$ & $26.26 \pm 0.19^{c}$ & $10.93 \pm 0.16^{\mathrm{c}}$ & $1.92 \pm 0.06^{\mathrm{a}}$ & $0.01 \pm 0.00^{\mathrm{g}}$ & $9.91 \pm 0.56^{\mathrm{cbd}}$ & $2.34 \pm 0.42^{\mathrm{dc}}$ & $0.05 \pm 0.00^{\mathrm{f}}$ & $56.08 \pm 0.35^{\mathrm{c}}$ \\
\hline & Sambucus nigra & $14.67 \pm 0.15^{\mathrm{a}}$ & $25.55 \pm 1.59^{\mathrm{c}}$ & $19.59 \pm 1.14^{\mathrm{a}}$ & $1.89 \pm 0.14^{\mathrm{a}}$ & $0.14 \pm 0.01^{\mathrm{ef}}$ & $97.32 \pm 5.58^{\mathrm{a}}$ & nd & $0.25 \pm 0.01^{\mathrm{c}}$ & $159.39 \pm 8.32^{\mathrm{a}}$ \\
\hline & Trifolium angustifolium & $2.83 \pm 0.45^{\mathrm{e}}$ & $19.60 \pm 0.53^{\mathrm{d}}$ & $7.52 \pm 0.62^{\mathrm{e}}$ & $0.04 \pm 0.00^{\mathrm{e}}$ & nd & $10.84 \pm 1.48^{\mathrm{cb}}$ & nd & $0.04 \pm 0.00^{\mathrm{gf}}$ & $40.87 \pm 0.13^{\mathrm{d}}$ \\
\hline & Tuberaria lignosa & $14.43 \pm 1.54^{\mathrm{ba}}$ & $9.80 \pm 0.25^{\mathrm{f}}$ & $2.44 \pm 0.10^{\mathrm{h}}$ & nd & $1.90 \pm 0.06^{\mathrm{b}}$ & $4.23 \pm 0.64^{\mathrm{fg}}$ & $6.69 \pm 0.52^{\mathrm{a}}$ & $0.03 \pm 0.00^{\mathrm{g}}$ & $39.51 \pm 1.33^{\mathrm{d}}$ \\
\hline Fruits & Rosa micrantha & $3.53 \pm 0.47$ & $7.96 \pm 0.54$ & $3.55 \pm 0.27$ & nd & $4.15 \pm 0.04$ & $34.71 \pm 0.79$ & nd & nd & $53.89 \pm 0.86$ \\
\hline
\end{tabular}

nd- not detected; tr- traces. In each column, different letters mean significant differences among samples $(\mathrm{p}<0.05)$. 


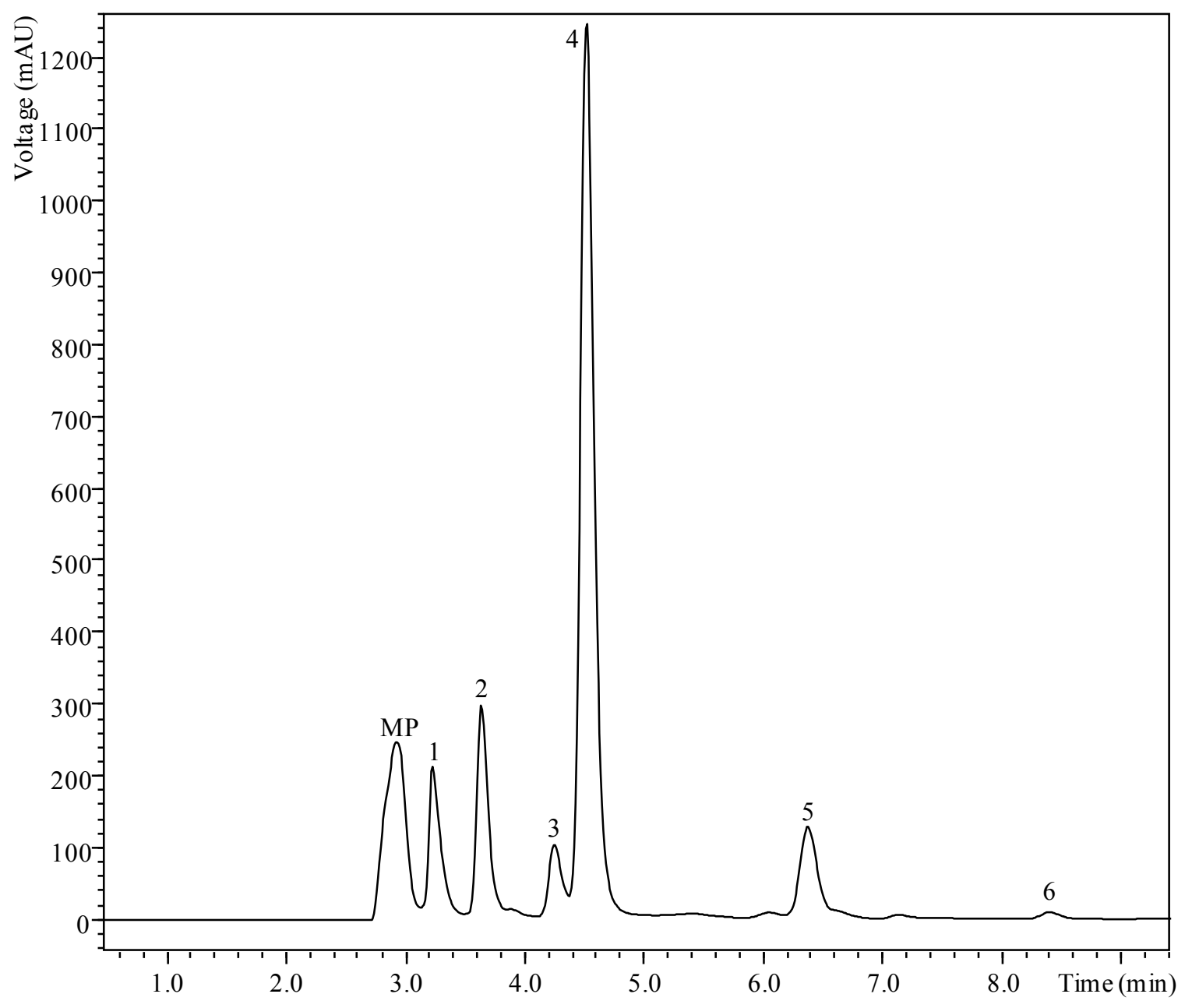

Figure 1. UFLC organic acids profile recorded at $215 \mathrm{~nm}$ of Arbutus unedo. MPmobile phase; 1- oxalic acid; 2-quinic acid; 3-malic acid; 4-ascorbic acid; 5- citric acid and 6- fumaric acid. 